\title{
The Challenges Faced by Informal Traders in Greater Letaba Municipality in Limpopo Province, South Africa
}

\author{
LEGODI, Kole | KANJERE, Matshidiso
}

\begin{abstract}
Tnformal trade has grown at an alarming

1 rate in South Africa because of lack of employment opportunities in both the private and public sectors. This has resulted in many unemployed members of the population joining the informal business sector. The majority of people in this sector do not have skills that are needed in the formal employment sector, others are semi-literate and a small percentage has some level of qualification. Nevertheless, this sector is plagued by a number of challenges which this article presents. The article reports on the study that was conducted at Greater Letaba Municipality in Limpopo Province. The aim of the study was to investigate the challenges that were faced by informal traders in Greater Letaba Municipality in Limpopo Province in South Africa. The

area was chosen because of its accessibility to the researchers and its potential to provide relevant and accurate information for the research project. Thus, a qualitative research method was used to collect data through face to face interviews. The research discovered that some of the challenges experienced by the informal traders in the area ranged from lack of support from the local municipality to structural challenges like lack of ablution facilities and limited access to electricity. Furthermore, other challenges concerned safety and health issues that were also gender based. Most of the traders in the area were women; an element which attest to the fact that it is difficult to find employment in the country when one is less educated and is also a woman.
\end{abstract}

Keywords: informal sector, traders, small businesses, entrepreneurship, developing economy. 


\section{Introduction}

This article discusses the legislative framework governing small businesses in South Africa, literature review on challenges faced by informal business sector, research methodology, findings and recommendations.

It has been estimated that approximately 1 million businesses operate outside the formal economy in South Africa and about 1, 8 million people are employed in these informal businesses (SBP,2005; Roux and Klaaren: 2002). BEES (2005) state that internationally, SMMEs are noted for their contribution to innovation and their ability to impact on growth. Small and medium-sized enterprises account for 60 to 70 percent of jobs in most SADC (Southern African Development Co-operation) countries; they also account for a disproportionately large share of new jobs (OECD, 2007). However, the OECD study (2005) also noted that many start-ups do not survive for more than five years and fewer still develop into high-growth firms. The Department of Trade and Industry (DTI) (2013) argues that the promotion of entrepreneurship and small business remains an important priority of the government of South Africa.

\section{Legislative Framework Concerning the Informal Sector in South Africa}

There is no direct legislation that governs informal business sector in South Africa, however it is generally accepted that the legal framework governing the Small, Medium and Micro sized Enterprises (SMMEs) sector, also governs the informal sector. According to the Business Enterprise Entrepreneur Support (BEES, 2005) in South Africa, the small, micro and medium-sized economic (SMME) sector has been promoted since 1995 in order to meet national economic growth objectives. BEES (2005) argues that despite ongoing government initiatives such as the formal launching of the Small Enterprise Development Agency by the department of trade and industry in 2004, the situation of most SMMEs remains highly problematic.

The commitment of government in the small business sector is to ensure that small businesses progressively increase their contribution to growth and performance of the South African economy in critical areas, such as job creation, equity and access to markets. Since 1994, with the advent of a new democratic era, South African government has taken measures to ensure that small business development becomes a key policy focus. 
The Challenges Faced by Informal Traders in Greater Letaba Municipality in Limpopo Province 59

In March 1995 an important milestone was achieved when government released its White Paper on national strategy for the development and promotion of small business in South Africa, the first time a comprehensive policy and strategy on small business development was formulated in the country.

- (Ministry of Trade and Industry, 2005, Integrated Strategy on the Promotion of Entrepreneurship and Small Enterprise Development)

The DTI (2005) makes a further addition to the framework and argues the crucial barometer for the success of the Integrated Strategy on the Promotion of Entrepreneurship and Small Enterprises is the continued creation of new start-up firms by all segments of society and in all corners of our country resulting in the improvement of economic and social well-being of the poor communities.

The DTI (2012) argues that the Small business sector has both the potential as well as the historic task of bringing millions of people from the survivalist/lower level including the informal economy to the mainstream economy. Constraints to new entrants in the SMME sector should be unblocked through the provision of adequate support to ensure that SMMEs survive the harsh introduction to the stiff competition of big business in the mainstream economy.

According to the DTI (2013) there are efforts to address market failures, particularly where they impact on the government's special development goals. Therefore, the government will continue to develop and implement measures focused on targeted beneficiaries, including microenterprises; informal enterprises; enterprises owned by black people, women and youth; growth-orientated enterprises; as well as enterprises in priority sectors like tourism, construction, agriculture, cultural industries and information and communications technology (ICT).

\section{Small business support since 1995}

According to the DTI (2013) the 1995 White Paper identified a number of constraints facing small enterprises. These relate to the legal and regulatory environment, access to markets, access to finance and affordable business premises, the acquisition of skills and managerial expertise, access to appropriate technology, the tax burden, and access to quality business infrastructure in poor areas or poverty nodes. 
The DTI (2013) argues that various key players in the South African economy share the importance of investing in stimulating small business. The growing and widespread commitment to fostering entrepreneurship and promoting small enterprises goes beyond the government and its institutions. It extends to other actors in the economy, such as large corporations, the media, non-governmental organizations (NGOs), chambers of commerce and commercial banks.

The DTI (2013) points out that this is evidenced by the growing number and range of support programmes, products and services initiated by the various players that have emerged both inside and outside the public sector. The promotion of entrepreneurship and small business remains an important priority of the South African government. In March 1995, the government released a White Paper on National Strategy for the Development and Promotion of Small business in South Africa, in which an elaborate policy and strategy framework on small business development was delineated. The DTI (2013) also pointed out that the government has developed mechanism of reducing tax burden for small enterprises.

\section{Access to finance}

The DTI (2012) argues it offers a wide range of products and services comprising loans, and incentive grants that play an important role in enabling access to finance for small enterprises through the following instruments and institutions:

The South African Micro-Finance Apex Fund (SAMAF) has been established to provide access to micro-loans and support to the social capital mobilisation. It has a national footprint. Khula Enterprise Finance Limited, tasked with facilitating access to finance, has developed a variety of financing products including credit guarantee schemes in which it has partnered with the country's major commercial banks to unlock lending to small enterprises. The Thuso Mentorship Scheme provides business plan development and other advisory assistance to small enterprises seeking to access finance under the Credit Guarantee Scheme (the DTI 2013).

The DTI (2013) argues that Khula continues to seek new ways to improve access to financial support across the country. "This includes partnering with sector departments to develop new sector-specific financing programmes for small business, and studying 
The Challenges Faced by Informal Traders in Greater Letaba Municipality in Limpopo Province 61

different approaches to strengthen the realisation of government goals for small business finance" (the DTI 2013).

The National Empowerment Fund (NEF) offers a range of start-up, business growth, and rural- and community-upliftment financing products with a focus on black economic empowerment (BEE) transactions. Through its various business units, the Industrial Development Corporation (IDC) provides sector-focused financing products ranging from R1 million upwards, with designated finance products focused on small business development and black economic empowerment (the DTI 2013).

An important development is the collaboration in product design among the development finance institutions to close the critical financing gaps for small businesses. Provincial development corporations are organs of state that further provide small financing products and other support measures. Provincial and national based enterprises provide a range of financial services (the DTI 2013).

In addition to the above, there is a range of sector-focused access to credit instruments created by other departments and their institutions, example, the Land Bank and the Micro-Agricultural Financial Institute of South Africa (MAFISA), under the Department of Agriculture.

\section{Business development services}

The DTI (2013) argues in line with its mandate for the retail rather than the wholesale model of service provision. The Small Enterprise Development Agency (Seda) is spreading its presence countrywide through branch offices and a network of independent partners, with a view to increasing access to business-development services.

Provincial government agencies such as the Gauteng Enterprise Propeller (GEP) in Gauteng, Limpopo Business Support Agency (Libsa) in Limpopo, and the Western Cape's Red Door continue to provide a range of business-development services to small enterprises at provincial level strengthening partnerships with Seda. Many municipalities also offer small 
business support under their local economic development agencies, or dedicated small business and co-operative programmes within their LED divisions and public-private partnership-based business-incubation centres (the DTI 2013).

\section{Youth enterprise development}

The DTI (2013) goes further to state that since 2001, the Umsobomvu Youth Fund (UYF), an agency dedicated to youth development, has been providing various financial and business-development products to this target market, some in partnership with privatesector financing institutions. A linkage programme links youth-owned small enterprises to procurement opportunities in the corporate sector, state-owned enterprises (SOEs) and government. However, UYF is defunct and has been replaced by the National Youth Development Agency (NYDA).

UYF has established a number of funds - the SME Fund, the UYF Business Partners Franchise Fund and the UYF-FNB Progress Fund - which offer finance to young entrepreneurs and include micro-loans as well as funds to expand, buy into or buy out existing businesses, or start new businesses. Partnerships established with the private sector are leading to the establishment of dedicated funds for target groups (the DTI 2013).

The DTI (2013) points out that the UYF is also implementing the country's first business-development services voucher programme to assist young entrepreneurs to access quality business development services. The fund also offers entrepreneurship training for scholars and out-of-school youth. The aim is to introduce entrepreneurship education in schools countrywide.

\section{Support for women-owned enterprises}

The Government has initiated various measures to increase women entrepreneurship and to support women in business. These include: Sawen (South African Women Entrepreneurs' Network), a DTI-initiated national networking forum for individuals and organisations committed to the promotion and advancement of women entrepreneurs.

Sawen represents and articulates the aspirations of women entrepreneurs, and holds organised educational and trade missions for members. Business linkages between SA 
women entrepreneurs and their counterparts in other parts of the world have also been facilitated. Sawen continues to be an advocacy network for women in business, ensuring that policies and strategies are sensitive to gender issues.

TWIB (Technology for Women in Business) is a DTI initiative that supports the advancement of women in business through the application of science and technology in their ventures. This is aimed at overcoming constraints to enterprise innovation and growth, as well as fostering local and global competitiveness. The sector departments have also developed initiatives to give targeted support to women in business. These have led to a grid of sector-specific women in business networks, including Sawic (construction sector), Woesa (oil and energy sector), and Sawima (mining sector).

Thus, irrespective of all the legislation supporting small businesses, most South African population still battle to access these institutions and to receive the much needed help.

\section{THE CHALLENGES FACING THE INFORMAL SECTOR IN SOUTH AFRICA}

\section{General challenges facing the informal sector}

According to Saunders and Loots (2006:92) one of the key challenges faced by the informal economy in South Africa is vulnerability to microeconomic and macroeconomic trends. For an example, the sales of vegetables and fruit in major retailers negatively affect the market share of street traders. Another challenge facing the informal sector is the relative lack of government support for the informal economy. Uys and Blaauw (2007:245) state that the informal or second economy is familiar with all levels of government as representing a real and significant component of the South African economy, but despite this, at the national government level, there are no coherent policies specifically tailored to support the informal economy.

Nevertheless, at the provincial and local government levels, initiatives have been made to map the informal economies of some provinces and some measures have been proposed. For an example in Gauteng, it has been proposed that urban planning should provide opportunities for small businesses in the informal economy to have access to centrally located and affordable premises. Uys and Ligthelm (2006:258) pointed out that the government had not in the past made any conscious efforts to support informal sector 


\section{Pejorative perceptions of the informal economy}

Pejorative perceptions of the informal economy - both within municipalities and some formal businesses - have contributed to the marginalization of the informal economy within official economic development policy. According to The South African LED Network, this marginalization is illustrated in the almost complete absence of reference to the informal economy in official planning and economic strategy documents, bar the document on SMME's development from the DTI.

The other negative perception with regard to informal sector is that government does not collect tax revenue from the informal sector to fund the development of the sector or the country, therefore, the sector should not complain about getting any necessary support from the government.

\section{Lack of appropriate policies from government}

From a government viewpoint, numerous factors add to the difficulty of putting together appropriate policies towards the informal economy. These factors include instability and vulnerability of informal workers' representation and associations; proliferation of organizations representing informal workers in each city or town; complex co-ordination processes within municipalities, each using its own strategies as well as low literacy levels resulting in informal workers being unable to exercise their constitutional rights and duties.

Furthermore, informal businesses are constantly harassed by police. Munyaradzi (2012:24) state that the relationship between the informal sector and police is usually strained, especially because the law enforcement agents are viewed as being antagonistic to the informal trading sector

In arguments attributed to Chenga (2013:10), the streets of major cities and towns in South Africa are a typical example of the dangers of an unbridled informal sector and because the informal sector is not answerable to anyone, it thrives on chaotic governance to a point that the speed with which vendors return back to the streets each time they are driven away by police indicates the extent of South Africa's unemployment rate and how this unemployment rate crisis is taking its toll on ordinary citizens.

Munyaradzi (2012:25) points out that because of the poor remuneration among some of the employed, members of the police service have taken advantage of the situation in which the practitioners in the informal economy find themselves, and such police officers 
end up soliciting bribes or some other favours from the vendors. The author goes on to argue that at times such members will offer protection to the vendors at a fee and in certain instances the police officers give vendors prior warnings before raids are conducted. "At times goods confiscated by the corrupt police officers end up being sold in the suburbs, where officers' wives or relatives and friends also operate market businesses to survive" (Munyaradzi 2012:26).

Chenga (2013:11) argues that because the informal sector is neither taxed nor monitored by government nor included in the gross national product (GNP), which is the market value of all products and services produced in a year by a country, it has been one of those areas the South African government has had serious challenges trying to control. "It will require a multi-pronged approach that addresses the issues from a regulatory, planning, moral, as well as human relations perspectives. Firstly, the authorities must develop people-friendly yet order-promoting policies in the transport and informal trading sectors. One of the biggest weaknesses of urban authorities in South Africa has been lack of policies. As a result there are no formal positions on most key issues" (Munyaradzi 2012:23).

"Successful cities, from a liveability point of view, have policies to manage every sector including vending, urban agriculture, and urban transport. Managing cities should not be a discretionary function of officials but they should be guided by policies prepared in an open manner and secondly there must be plans for all these activities. One should go to the city and be shown a comprehensive informal sector plan indicating areas and conditions" (Munyaradzi 2012:23).

Chenga (2013:14) argues that workers in the South African informal economy are generally not covered by adequate social protection and existing social insurance mechanisms are generally not adapted to the structure of the labour force and access to social assistance programmes is limited. This makes informal workers a very vulnerable and sizeable proportion of the South African population. "South African informal sector work forces are mainly made up of unwaged agricultural workers, self-employed workers, micro-business employees, petty traders and so forth" (Chenga 2013:15). 


\section{Gender based challenges}

Siqwana-Ndulo (2007:12) maintains that in South Africa the informal sector is over represented by women who come from previously disadvantaged backgrounds. These women find it difficult to operate because municipal by-laws make it difficult for survivalist street traders to trade and in some instances goods belonging to the traders are forcibly taken; this affect women the most as they are the soft targets of the police and other perpetrators. In Greater Letaba Municipality area, women are also afraid of trading after hours because of fear of being attacked or their goods forcibly taken.

Furthermore Siqwana-Ndulo (2007: 18) argues that female street traders face diverse work environment risks and dangers that put them at high risk of illness due to exposure to the elements and hazardous work environments. According to Barker (2007:46) one of the common biggest fears for both men and women street traders are theft and criminal violence. However, women are more vulnerable to the serious risk of sexual assault which can expose them to HIV/AIDS especially in a country such as South Africa which has one of the highest prevalence rates. Sometimes persistent low incomes facing women traders and lack of financial security can make these women take risky decisions and be exposed to HIV/AIDS. Horn (2011:16) further argued that women street traders experience high stress levels due to working long hours and discharge of household responsibilities after work.

The low level of education of women traders makes it hard for them to get enough money to employ household workers. Structural and societal issues had made most South African women not to go far with their education. Rasool (2012:25) agrees that various structural and social issues in South Africa had contributed to low education levels for women as compared to men. As a result fewer women can read and write and this deficiency limits their ability to understand written instructions, rules and by-laws as well as information that could help them improve their businesses.

Kester and Ogunyika (2007:05) maintain that the other challenge for women traders include lack of provision of child care facilities which should be provided by the state. Limited child care facilities are provided by non-governmental organizations (NGOs) and churches. Henley and Arabsheibana (2009: 992) argue that these services that could also be of assistance to women traders are difficult to access. Sometimes women traders divide their attention between work and child care, where possible, relatives assist in caring for the young ones. 
Siqwana-Ndulo (2007: 18) explained that the South African State has been found to give negligible support to child care facilities, and the little support that is provided is still distributed along the racial lines. Race also affects accommodation issues, as African women were not allowed to stay in the cities previously. They are now forced to commute between the cities and their rural homes, because accommodation in the cities is expensive and they cannot afford it. Pillay (2004:35) contends that historically African women were prevented from living in the cities except as domestic workers and subsequently, they did not acquire accommodation in the cities.

The government of the day has brought about change in laws governing the country and a number of promises, some of which have not been met; amongst such policies are those that promise to equip traders with skills. Siqwana-Ndulo (2007:18) maintains that promises to equip traders with skills and support to secure financial assistance have not been fulfilled. Pillay (2004: 39) argues that when juxtaposing the formal and the informal sector, it becomes apparent that those operating in the informal sector bear the brunt of socio-economic and health issues. Unlike in formal employment, the formal sector does not have protection of labour legislation and social protection measures such as insurance, disability, maternity, and unemployment benefits. Henley and Arabsheibana (2009: 992) argue that the situation is dire for people who work in the informal sector. There is a need to develop the informal sector and to assist women traders to boldly raise their concerns in relevant forums. Municipalities should be encouraged to play an active role in supporting the informal traders in their areas.

\section{RESEARCH METHODOLOGY}

\section{Aim of the Study}

The aim of the study was to identify the factors contributing to challenges of informal traders in Greater Letaba Municipality. The study therefore, also highlighted the profile and the operations of the informal traders in the area.

\section{Objectives of the Study}

- To identify challenges faced by informal traders in Greater Letaba Municipality

- To understand whether some challenges were gender based. 


\section{Research Questions}

- What were the challenges faced by informal traders in Greater Letaba Municipality?

- Were challenges faced by informal traders' gender specific?

\section{Choice and Rationale of Research Design}

The study employed qualitative research approach because the approach allowed the researcher to focus on the phenomena as it occurred on its natural settings (Leedy and Ormrod 2014: 141). Therefore, informal traders were studied at their place of operation.

\section{Population}

The target population was the informal traders in Greater Letaba Municipality. The study focused on informal traders who mostly traded in fresh produce vegetables obtained from various towns, like Modjadjiskloof, Tzaneen, Polokwane and Letsitele. It has been observed that these traders mostly trade during the day. Since there was no database for the correct statistics of these traders, the estimated population in the area was put at 27.

\section{Sample, Sampling Methods and Sample Size}

The entire population was included in the study since it was manageable. Nevertheless, Burger et al (2006:1) states that the most common sampling methods is non-probability sampling which include purposive sampling and quota sampling. But in instances where there is a reasonable number of population, the entire population may be included in the study. Thus, a total of 27 participants trading in Mooketsi area were identified and selected to participate in the study.

\section{Data Collection}

Primary and secondary data were collected. Primary data was collected through interviews and secondary data through literature review and other form of documentation. Leedy and Ormrod (2014:155) contend that interviews can yield a great deal of useful information, especially because researchers can ask questions in relation to biographical information, peoples' present and past behaviours. 
The Challenges Faced by Informal Traders in Greater Letaba Municipality in Limpopo Province 69

\section{Data Analysis}

Data was sorted, categorized and analysed through identified themes. The voice recorders enabled the researcher to listen to the participants' responses over and again when analysing data.

\section{Research Findings}

The following are the findings of the study:

- In Greater Letaba Municipality area women formed the majority of traders in the informal sector.

- Most traders in the area have a low level of education and the informal sector serves as a refuge.

- Some participants indicated that their decision to sell goods in the informal sector was influenced by their economic dispensation.

- Other participants indicated that their businesses have been inherited from their predecessors.

- Women participants also indicated that gender plays a role in their businesses as some have to balance work and family environments, and be cautious of safety issues more than their male counterparts.

- Lack of support from government and municipalities was listed as a major obstacle.

- Other participants listed difficulty to access finance as a great challenge in their businesses.

- Other listed challenges included lack of access to electricity, ablution facilities and child care facilities.

\section{Discussions}

Informal sector is a common phenomenon in most underdeveloped or developing economies. It has been created by lack of employment opportunities in both the public and private sectors. Pedersen (2006:67) argues that in developing countries, the informal 
sector plays a significant role in the economic sector because it creates employment opportunities and contributes to trade of goods between people.

Furthermore, the informal sector is attractive to the larger population because it offers low resistance to entry, there is no formal education that is required or any form of experience. Solomon (2011: 239) agrees that the informal sector in most developing countries is characterized by low barriers of entry and as a result many people in the informal sector do not pay taxes. In South Africa, the informal sector is also populated by people with low level of education. Some people find the sector attractive because they do not have to contribute towards tax revenues.

Pedersen (2006:72) argues that in most countries on the African continent, the growth of the informal sector results in a loss of revenue for the government. The government should therefore, encourage the informal traders to join the formal sector by having their companies registered as small businesses. However, Rajesh Raj, Sen and Kathuria (2014:39) argued that in many developing countries such as India, potential entrepreneurs prefer operating in the informal sector, primarily as a way to avoid registering their potential businesses with authorities. It will therefore be important for the government of South Africa to demonstrate the importance of growing the economy of the country through both formal and informal sector. Guibin (2008:659) maintains that the economic development of China since 1978 was obtained as a result of the new private sector which was supported through formal and informal channels.

Bohme and Thiele (2014: 1369) argue that in a developing economy there is evidence of a need for informal sector services and it is a normal business function that is motivated by supply and demand of such products. Governments of developing economies should thus develop mechanisms of providing support for the informal sector through building the necessary infrastructure and facilitate access to funding. Rajesh Raj et al (2014:38) state that one of the most important tools in creating a new business, be it formal or informal, is access to finance because there is a positive correlation between ease of access to finance and entrepreneurs having the ability to create new businesses. Namrata (2013:265) argues that the government has to promote growth and access to finance because an increase in the unemployment rates has a direct effect on poverty and inequality.

Traders in Greater Letaba Municipality area did not mention harassment by police as one of their challenges. This implies that the municipality in the area is indirectly 
promoting their sector, because in certain parts of the country, especially in the big cities, informal traders are constantly harassed by policemen and in some instances some of their goods are confiscated. Nevertheless, the municipality does not provide basic infrastructure such as ablution facilities or child care facilities.

Access to finance is another major challenge that was mentioned, the government should facilitate access of funds for traders as one of mechanism of growing and supporting the informal sector. This will enable the government through relevant municipalities to regulate the sector.

Empirical evidence has also revealed that the informal sector is closely linked with the formal sector in Greater Letaba Municipality, in the sense that most of the goods sold in the informal sector are bought from the formal sector which is characterized by formally registered and formally regulated businesses. The formal sector produces, distributes and provides services to the informal sector which in turn boosts the sales of the formal sector. Thus, growth in the formal sector, impacts on growth in the informal sector. In the same vein, the economic slowdown of the formal sector affects the informal sector.

\section{Conclusions}

The results from the research in relation to the challenges faced by the informal sector traders in Greater Letaba Municipality revealed that services rendered by the informal traders are demand driven, hence some of the traders have decided to trade 24 hours even by candle light. Selling of skills are some of the services directly associated with the trading activities that are provided by the informal sector. Authorities, local, provincial and national governments have not done much to understand and improve the conditions under which the informal traders operate.

The informal sector is highly volatile in terms of labour relations in that the revolving door has no mechanisms to stop it. In most cases, labour is provided by relatives or siblings or even spouses when the other party is engaged in some activities. The informal sector in Greater Letaba Municipality does not play a major role in absorbing a large number of employees; however it plays a significance role to those involved in it. Hence, no efforts have been made by the Greater Letaba Municipality to understand the informal labour market.

Appropriate policies aimed at assisting respondents in the informal sector can include the development of skills, training and support in terms of infrastructure. The other 
support that should be considered is access to finance. Most traders in the informal sector struggle with access to credit and without access to credit, business expansion becomes a nearly impossible goal to achieve. Banks and other formal financial institutions do not extend credit facilities to informal traders.

Government should focus on the informal sector so as to bring about changes that will move the sector from being largely survivalist and marginal to fully participate and take part in the local economy. The relationship between the informal sector and the formal sector in Greater Letaba Municipality display the characteristics of symbiosis. Therefore, the two sectors should develop mechanisms of working together with the view of upgrading the informal sector. Significant economic growths in South Africa need active participation of both sectors.

\section{Recommendations}

Some of the challenges facing the informal traders are inherent in the business model and others can be resolved. Therefore, this article will focus on challenges that can be resolved.

- This article recommend that training be provided by the local municipality and other Non-Governmental Organisations, as well as other state agencies such as Limpopo Economic Development Agency, Small Enterprises Development Agency and Small Enterprises Finance Agency. Training in business management, marketing management, financial management and basic record keeping is essential and it will contribute to the overall management of the informal businesses.

- It is further recommended that training be conducted in a manner that will not take away the traders from their business site. These traders are engaged in this trading as a way of making a living and thus should not be disturbed in their businesses. The training they receive should be tailor made to suit their business and their level of education. One size fits all, should be avoided as far as resources can allow. One size fits all has been proven to be ineffective in certain aspects.

- The study also recommends that local municipality provide ablution and child care facilities. Electricity should also be made available to the traders, and a 
The Challenges Faced by Informal Traders in Greater Letaba Municipality in Limpopo Province 73

reasonable amount be charged for maintaining accessible facilities and rates for electricity.

- The study further recommends that support be provided through relevant legislation to the traders, so as to improve their safety and security.

\section{List of References}

- Barker, A.P. (2007), The informal sector and skills development. South African Journal for Human Resources, 5 (4), p 45-49.

- Bohme, M. and Thiele, R. (2014), Informal-formal Linkages and Informal Enterprise Performance in West Africa., European Journal of Development, 6, p. 1369.

- Business Enterprise Entrepreneur Support (2005). (Online). Impact of Business Regulations on SMME's. Available from www.bees.org.za (Accessed: $12^{\text {th }}$. July.2014)

- Chenga, N. (2013), Business dynamics of the informal business sector, Business Horizons, 44 , pp. $10-15$

- Department of Economic Development, Environment and Tourism (2014). (Online). LED Strategy in Limpopo. Available from www.ledet.gov.za (Accessed: 24th. August.2014)

- Department of Trade and Industry. (DTI). (2014). (Online). DTI Strategy on SMME. Available from www.DTI.gov.za (Accessed: $11^{\text {th }}$.August. 2014)

- Department of Trade and Industry (DTI). 2005. Integrated Strategy on the promotion of entrepreneurship and small enterprises.

https://www.thedti.gov.za/sme_development/docs/strategy.pdf. (Accessed: $12^{\text {th }}$. July.2014)

- Guibin, J. (2008). The Informal Sector and Growth in China. Eco-Environmental Sciences, 4(2), p. 659.

- Henley, A. and Arabsheibana, G.R. (2009), Defining and measuring the informal sector. African Technical Families Poverty Reduction and Economic Management, 20, p. 992.

- Kester, K.O. and Okunyika, K.O. (2007), Broadening Labour Relations beyond the formal sector: The challenges of the informal sector in Nigeria, Ife PsychologyIA, pp. 3-11. 
- Leedy, P.D. Ormrod, J.E. (2014), Practical Research: Planning and Design, 10 $0^{\text {th }}$ Edition, England, Pearson International

- Ligthelm, A.A. (2013), Size Estimate of the South African Informal Sector. Southern African Business Review, 10 (2), pp. 55-70.

- Ligthelm, A.A. (2013), Confusion about Entrepreneurship? Formal versus Informal Businesses. Southern African Business Review, 17 (3), pp. 55-60

- Munyaradzi, F. (2012), Economic instability of the South African informal sector. Acta Academica, 6, pp. 22-26.

- Namrata, T. (2013), Inclusive Growth and Institutions: An Analysis of the employment structure in India's Tea Plantation Sector. African Journal of Science, Technology, Innovation and Development, 5 (3), pp.264-265.

- Organisation for Economic Cooperation and Development. OECD. 2007. Young SMEs, growth and job creation. www.oecd-org/sti/young-sme-growth-and-job-creation.pdf

- Pedersen, P.O. (2006), Trade and Traders: A Dynamic Factor in the small and micro enterprises in Kenya and Other Countries in Eastern and Southern African Countries. Danish Institute for International Studies, 1(1), pp. 66-74.

- Pillay, P.L. (2004), A Socio Economic Analysis of African Female Street Traders in the Johannesburg CBD. South African Journal of Economic and Management Sciences, 7 (1), pp. 23-29.

- $\quad$ Rajesh Raj, S.N., Sen, K. Kathuria, V. (2014), Does Banking Development Matter for new firm creation in the informal sector? Evidence from India. Review of Development Finance, pp. 38-39.

- Rasool, F. (2012), Challenges facing informal sector micro-enterprises in Newlands West, University of Kwazulu-Natal, pp. 18-30

- Roux, T. and Klaaren, J. 2002. Regulation Review: Notes Towards an Appropriate South African Model: Research Paper Commissioned by GTZ. Centre for Applied Legal Studies and Wits Institute for Social and Economic Research. University of the Witwatersrand. http://www.law.wits.ac.za/cals/It/pdf.

- Saunders, S. and Loots, E. (2006), Measuring the informal economy in South Africa. South African Journal of Economic and Management Sciences,8 (1), p 92.

- Strategic Business Partnerships for growth in Africa. (SBP). 2005. Main Report: Counting the cost of red tape for business in South Africa 
The Challenges Faced by Informal Traders in Greater Letaba Municipality in Limpopo Province 75

- Siqwana-Ndulo, N. (2011), The Informal Sector in South Africa: Women street traders in Durban. Consultancy Africa Intelligence, pp. 12-21.

- Sarbajit, C.and Ujjaini, M. (2013), Revisiting the Informal Sector. European Journal of Development, 4, p. 206.

- Solomon, O.H. (2011), The Effect of Social Policy on the Size of the Informal Sector in Nigeria. London Metropolitan University, pp. 238-257.

- Uys, M.D and Blaauw, P.F (2007), The Dual Labour Theory and the Informal Sector in South Africa, Acta Commercii, p. 240-265.

- Uys, A. and Ligthelm, A.J (2006). The correlation between the formal and informal sectors in Pretoria. South African Journal for Human Resources, 2 (4), p 248.

\section{AUTHORS' CONTACT:}

\section{LEGODI, Kole KANJERE, Maria}

Turfloop Graduate School of Leadership Turfloop Graduate School of Leadership University of Limpopo University of Limpopo

Email: $\quad$ Email: maria.kanjere@ul.ac.za 